\title{
Application of Orem's theory on wounds: an integrative review
}

\author{
Aplicação da teoria de Orem no âmbito das feridas: uma revisão integrativa
}

\section{Aplicación de la teoría de Orem en el área de las heridas: una revisión integrativa}

\begin{abstract}
Larissa Houly de Almeida Melo 1,*, Thaís Honório Lins Bernardo1, Jane Keyla Souza dos Santos Macedo1, Leilane Camila Ferreira de Lima Francisco ${ }^{1}$, Alice Correia Barros ${ }^{1}$
\end{abstract}

ORCID IDs

Melo LHA (D) https://orcid.org/0000-0002-6397-1803

Bernardo THL (D) https://orcid.org/0000-0002-8058-8400

Macedo JKSS (D) https://orcid.org/0000-0002-5037-097X

Francisco LCFL (D) https://orcid.org/0000-0003-4945-8939

Barros AC (D) https://orcid.org/0000-0002-2627-7185

\section{HOW TO CITE}

Melo LHA; Bernardo THL; Macedo JKSS; Francisco LCFL; Barros AC. Application of Orem's theory on wounds: an integrative review. ESTIMA, Braz. J. Enterostomal Ther., 18: e0920, 2020. https://doi. org/10.30886/estima.v18.821_IN

\begin{abstract}
Objective: To characterize the scientific production on the application of Orem's self-care theory in the scope of wounds. Method: Integrative literature review with the available articles that highlight the theme. The following informational resources were used: VHL, CINAHL, Scopus, Cochrane, PubMed and SciELO. The following descriptors were listed: Self Care, Nursing Theory, Wound and Ulcer, in their English and Portuguese versions. The final sample consisted of 10 publications. Data were collected using a validated tool. Evaluation and data synthesis were produced through description and simple statistical evaluations. Results: The analyzed researches were developed in four countries; English language was predominant; publications began in 2004. The theory was applied in nursing care systematization, as a teaching strategy for self-care and as a theoretical framework. The articles linked the theory to diabetic foot, venous ulcer, leg/lower limb ulcers (no specification of type), burns and pressure injury. Conclusion: Orem's theory was applied to a variety of individuals and contexts, its applicability within the scope of wounds is something concrete, regardless of the type of injury.
\end{abstract}

DESCRIPTORS: Self Care. Nursing theory. Wounds and injuries. Leg ulcer. Enterostomal therapy.

\section{RESUMO}

Objetivos: Caracterizar a produção científica sobre a aplicação da teoria do autocuidado no âmbito das feridas. Método: Revisão integrativa da literatura com os artigos disponíveis na íntegra que evidenciem a temática. Foram utilizados os seguintes recursos informacionais: BVS, CINAHL, Scopus, Cochrane, PubMed e SciELO. Foram elencados os seguintes descritores: Autocuidado, Teoria de enfermagem, Ferida e Úlcera, em suas versões em inglês e português. A amostra final constou de 10 publicações. Os dados foram coletados utilizando um instrumento validado. A avaliação e a síntese dos dados foram produzidas através de descrição e avaliações estatísticas simples. Resultados: Os estudos analisados foram desenvolvidos em quatro países, o idioma inglês predominou e as publicações tiveram início em 2004. A teoria foi aplicada na sistematização da assistência de enfermagem como estratégia de ensino para o autocuidado e como referencial teórico. Os artigos relacionaram a teoria com pé diabético, úlcera venosa, úlceras de perna/ membros inferiores (sem especificar o tipo), queimaduras e lesão por pressão. Conclusão: A teoria de Orem foi aplicada a uma diversidade de sujeitos e contextos, sua aplicabilidade no âmbito das feridas é algo concreto, independentemente do tipo de lesão.

DESCRITORES: Autocuidado. Teoria de enfermagem. Ferimentos e lesões. Úlcera da perna. Estomaterapia.

1.Universidade Federal de Alagoas - Escola de Enfermagem - Maceió (AL), Brazil.

*Correspondence author: larissahouly@hotmail.com

Received: Nov. 13, 2019 | Accepted: Mar. 31, 2020 


\section{RESUMEN}

Objetivo: Caracterizar la producción científica sobre la aplicación de la teoría del autocuidado en el área de las heridas. Metodología: Revisión integradora de la literatura con artículos disponibles en su totalidad que evidencian el tema e indexados en recursos informativos: BVS, CINAHL, Scopus, Cochrane, PubMed y SciELO. Se enumeraron los siguientes descriptores: Cuidado personal, Teoría de enfermería, Herida y úlcera, en sus versiones en inglés y portugués. La muestra final consistió en 10 publicaciones. Los datos fueron recolectados utilizando un instrumento validado. La evaluación y síntesis de los datos se produjeron a través de la descripción y evaluaciones estadísticas simples. Resultados: Los estudios analizados se desarrollaron en 4 países, predominó el idioma inglés, las publicaciones comenzaron en 2004. La teoría se aplicó en la Sistematización del Cuidado de Enfermería, como estrategia de enseñanza para el autocuidado y como marco teórico. Los artículos relacionaron la teoría con pie diabético, úlcera venosa, úlceras en las piernas/úlceras de miembros inferiores (sin especificar el tipo), quemaduras y lesiones por presión. Conclusión: La teoría de Orem debe aplicarse a una variedad de temas y contextos, su aplicabilidad dentro del alcance de las heridas es algo concreto, independientemente del tipo de lesión.

DESCRIPTORES: Autocuidado. Teoría de enfermería. Heridas y traumatismos. Úlcera de la pierna. Estomatoterapia.

\section{INTRODUCTION}

Wounds are considered to be a serious public health problem because of the increased number of people with this condition. It is estimated that approximately $3 \%$ of the Brazilian population has some tissue impairment that characterizes skin lesion ${ }^{1}$.

As a result of the many consequences caused by wounds, these patients demand high costs from the health services, as they involve long-term and complex care ${ }^{2}$.

As a profession directly related to care, nursing acts in the teaching of self-care, which is a relevant strategy for dealing with problems related to the rehabilitation process ${ }^{3}$. Educational interventions that stimulate the practice of self-care are necessary, making the subject the protagonist of his health promotion ${ }^{4}$.

The Orem's general theory of nursing is composed of three interrelated theoretical constructs: the self-care theory, the self-care deficit theory and the theory of nursing systems, evidencing the importance of patient involvement for self-care ${ }^{5}$.

The cause of nursing actions to individuals in Orem's theory is related to the purpose of making them completely or partially able to conduct care for themselves or their dependents and to be able to continue to take measures to control or diminish factors that compromise the functioning and development of themselves or their dependents ${ }^{6}$.

The Orem's theory is one of the theoretical constructions that have most inspired the practice of Brazilian nursing ${ }^{4}$. The interest in the subject arose from the need to know how theory has been applied in the context of wound care.
Given the importance of the subject to the field of nursing, this research has as its guiding question "how is the self-care theory being applied in the field of wounds?", aiming to characterize the scientific production on the application of the self-care theory in the field of wounds.

\section{METHODS}

It is an integrative review of the literature that establishes a vast methodological challenge regarding the reviews, allowing the insertion of different types of studies for the global understanding of the studied phenomenon. This method has the potential to play an important role in evidence-based nursing practice ${ }^{7}$.

In order to design the study, steps were taken to develop an integrative review ${ }^{7}$ : identification of the theme and creation of the research question, establishment of inclusion and exclusion criteria, identification of preselected and selected studies, categorization of selected studies, analysis and interpretation of results, presentation of the review/knowledge synthesis.

For database research, the following descriptors were listed: Self-care, Nursing Theory, Wound and Ulcer, in their English and Portuguese versions. The descriptors were grouped in different ways using the Boolean operators $A N D$ and $O R$ to bring the subjects together simultaneously.

In the search strategy, six information resources were used, six informational resources were used, of which four were electronic databases (VHL, CINAHL, Scopus and Cochrane), the PubMed portal, which includes 
MEDLINE, and a digital library (SciELO). The search was performed in August 2019.

Studies addressing the self-care theory in the field of wounds were included, regardless of publication time and language. Articles not made available in full were excluded.

The studies were identified and selected according to the guiding question and inclusion criteria previously defined. The search strategy made it possible to elect the studies, which were initially evaluated through the analysis of the titles and abstracts. When the titles and abstracts were not sufficient to define the initial selection, the entire selection was read. The final sample consisted of 10 articles.

The evaluation and synthesis of the data were produced by means of description, making it possible to categorize and group the information produced on the subject. For this, the instrument already validated was used, which includes the following items: identification of the original article, methodological characteristics of the study and evaluation of the methodological rigor, the interventions measured and the results found. The use of validated instruments determines a common language among health professionals and related areas ${ }^{8}$.

Simple statistical evaluations of frequency distribution in percent were used to reliably characterize the sample in the response analysis step using the software Microsoft Excel 2010.

Therefore, this review discloses the results and conducts a discussion on the application of the self-care theory in the field of wounds.

\section{RESULTS}

The search strategy made it possible to cross the descriptors "Self-care", "Nursing theory", "Wound" and "Ulcer", in their English and Portuguese versions. The crossings (Self-Care AND Nursing Theory AND Wound OR Ulcer) obtained in the informational resources: VHL, CINAHL, Scopus and Cochrane, PubMed and SciELO, made possible a universe of 182 publications. There were 4 in SciELO, 70 in VHL, 55 in PubMed, 14 in CINAHL, 33 in Scopus and 6 in Cochrane. However, 69 publications were excluded by duplication, obtaining a universe of 113 .
After reading the titles, 92 publications were previously selected by approximation to the subject of the study. With the reading of the abstracts, 16 publications became potentially eligible, but 3 of these were not available for reading in full and 3 were discarded after reading in full because they did not meet the inclusion criteria. Therefore, this review included a sample of 10 publications for interpretative analysis. Fig. 1 presents the flowchart of identification, selection and inclusion of publications in the integrative review.

Among the 10 articles found in this review, the VHL was the database with the most publications, totaling 8 (80\%), followed by Scopus with 4 (40\%), PubMed with $4(40 \%)$, CINAHL with $2(20 \%)$ and $1(10 \%)$ in Cochrane. It should be noted that 5 (50\%) of these articles were present in a single database and $5(50 \%)$ were distributed in the others.

The sources of publications include different journals, all related to the nursing area (10 articles, 100\%). Nursing authors were identified in all surveys (100\%), noting that 4 (40\%) of these surveys involved nurses and other professionals or students. The number of authors per publication varied between 1 and 8 .

The studies analyzed were developed in 4 countries, of which 3 (30\%) in Brazil, 2 (20\%) in Germany, 2 (20\%) in Colombia, 2 (20\%) in the USA and 1 (10\%) in Iran. The English language predominated in 4 (40\%) articles and the others were indexed in Portuguese $(3,30 \%)$, Spanish (2, 20\%) and German (1,10\%).

As for the year of publication, publications started in 2004 , with only $1(10 \%)$ in 2019 . Subsequent publications were $1(10 \%)$ in $2006,1(10 \%)$ in $2007,1(10 \%)$ in 2008 , $2(20 \%)$ in 2009, 1 (10\%) in 2010, 2 (20\%) in 2017 and $1(10 \%)$ in 2018.

Regarding the methodological approaches, 1 experimental article (10\%), 2 qualitative, 2 experience reports, 2 reflection reports (thus obtaining 20\% in each category), 1 quasi-experimental, 1 validation and 1 correlation (with a percentage of $10 \%$ in each category) were found.

The reading of the articles made it possible to identify distinct categories concerning the application of the Orem's theory. To better describe them, they were delineated as follows $\left.{ }^{4}: 1\right)$ application of the theory in the systematization of nursing care (SNC); 2) application of the theory as a teaching strategy for self-care; 
$3)$ application of the theory as a theoretical reference. Thus, 4 (40\%) articles applied the theory as a teaching strategy for self-care, 5 (50\%) applied the theory as a theoretical reference, and 1 (10\%) applied the theory for the realization of SNC.

By analyzing these articles, it was possible to identify the types of wounds that the authors related to the theory.
There were 3 (30\%) publications that related the self-care to leg ulcers/lower limbs, but without specifying the type. Other 3 (30\%) publications related the theory with diabetic foot, 1 (10\%) with venous ulcer, 1 (10\%) with burns, 1 (10\%) with pressure injury and $1(10 \%)$ with operative wound.

Table 1 ratifies the exposure of the main findings of each publication included in this review.

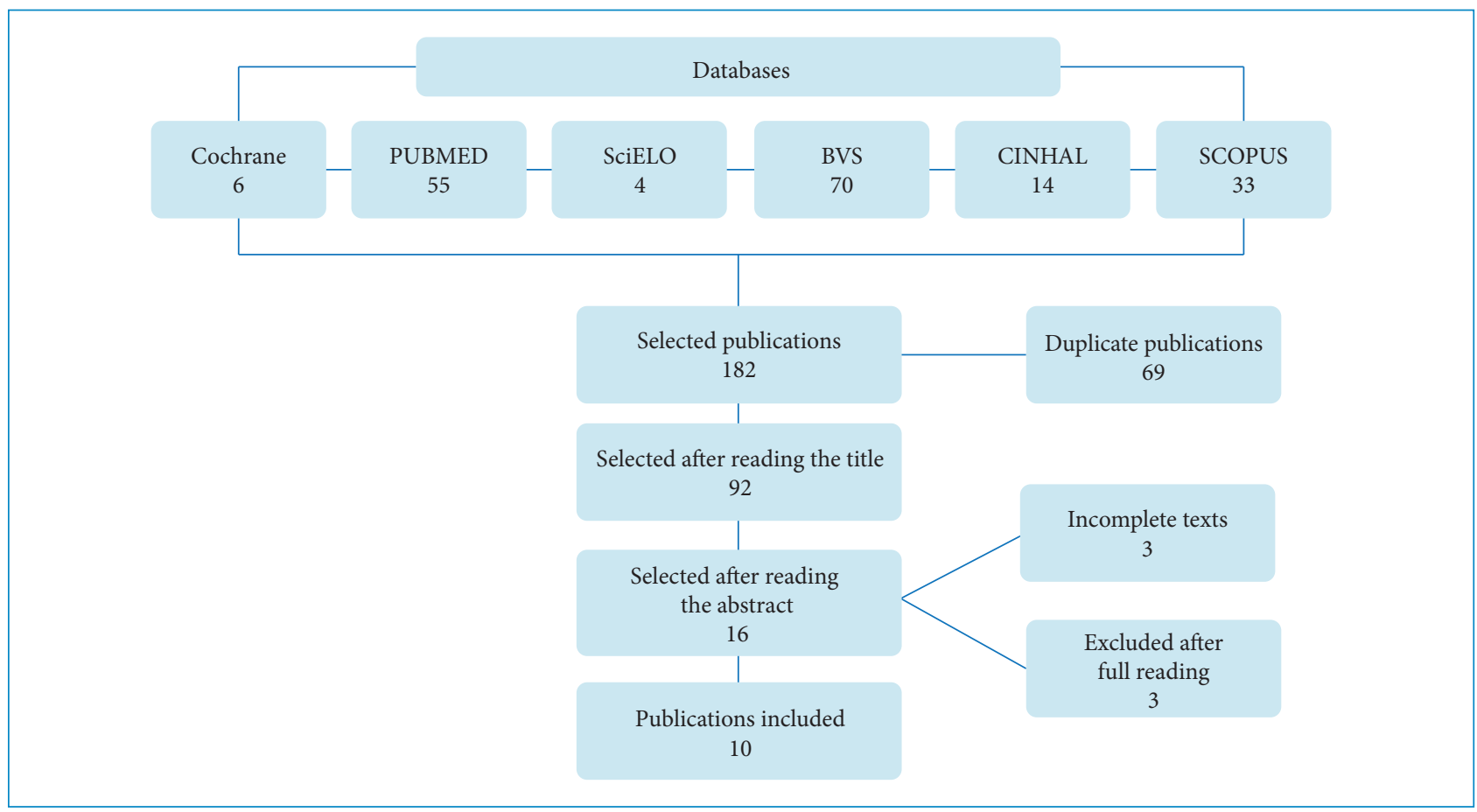

Figure 1. Identification, selection and inclusion of publications in the integrative review sample. Alagoas, 2019.

Table 1. Distribution of selected publications according to author, country, year, methodological approach, wound type and application of the theory. Alagoas, 2019.

\begin{tabular}{|c|c|c|c|c|}
\hline Author & Country/year & Methodological approach & Type of wound & $\begin{array}{l}\text { Application of the } \\
\text { theory }\end{array}$ \\
\hline Herber, Schnepp, Rieger ${ }^{9}$ & Germany/2008 & Case report & Leg ulcer & Teaching strategy \\
\hline Flores, Flores, Range $\left.\right|^{10}$ & Colombia/2010 & Experimental & Pressure injury & Teaching strategy \\
\hline Coelho, Silva $^{11}$ & Brazil/2006 & Case report & Diabetic foot & Teaching strategy \\
\hline $\begin{array}{c}\text { Maslakpak, Shahbaz, Parizad, } \\
\text { Ghafourifard }^{12}\end{array}$ & Iran/2017 & Quasi-experimental & Diabetic foot & Teaching strategy \\
\hline $\begin{array}{l}\text { Lima, Santos, Silva, Comassetto, } \\
\text { Correia, Ferreira' }\end{array}$ & Brazil/2017 & Qualitative & Surgical wound & Theoretical reference \\
\hline Consuegra ${ }^{14}$ & Colombia/2007 & Reflection & Leg ulcer & Theoretical reference \\
\hline $\begin{array}{c}\text { Garcia, Müller, Paz, Duarte, } \\
\text { Kaiser }^{15}\end{array}$ & Brazil/2018 & Qualitative & Leg ulcer & Theoretical reference \\
\hline Wilson, Gramling ${ }^{16}$ & USA/2009 & Reflection & Burn & Theoretical reference \\
\hline $\begin{array}{l}\text { Markuson, Hanson, Anderson, } \\
\text { Langemo, Hunter, Thompson }\end{array}$ & USA/2009 & Correlation study & Diabetic foot & Theoretical reference \\
\hline Panfil, Mayer, Evers ${ }^{18}$ & Germany/2004 & Validation & Venous ulcer & SNC \\
\hline
\end{tabular}




\section{DISCUSSION}

By discussing this study, the versatility of applying the Orem's theory in the field of wounds can be ensured. All publications occurred in nursing journals and all had nurses as authors. Identifying the professional formation of the authors is significant, because it allows to know the professional categories that most elaborate research on the subject in question. As this is a very specific subject, it is inferred that there is a predominance in the area of nursing ${ }^{19}$.

The publications were produced in four different countries. The leading country in publications was Brazil. The scientific production in the country has been growing and, today, it occupies the 13 th position in the world, with approximately 74 thousand articles in $2017^{20}$.

Although most articles are published in Brazil, English was the language with the highest indexing. This fact can be justified through the databases chosen for the search, since PubMed and Scopus have publications originally in English.

Regarding the types of studies, it was not possible to observe a methodological tendency. Academic productivity had no predilection for a specific type of study. Reaffirming the polyvalence of the application of this theory in different contexts in the area of nursing.

The use of Dorothea Orem's theory can be extended to different individuals and groups, providing timely nursing practice for the self-care needs of the individual and/or group 4 .

A significant number of publications have used the Orem's theory as a strategy for teaching self-care to patients with wounds. In these studies, the nurses analyzed the context lived by the patients, so that, together with them, they could develop and guide the practice of caring for themselves.

One of the articles in the integrative review reports the experience of developing an education program, led by nurses from Germany, aimed at helping patients with leg ulcers in their therapeutic demands for self-care 9

The study conducted in Colombia ${ }^{10}$ also used the Orem's theory as a teaching strategy. The authors evaluated the effectiveness of an educational intervention program, based on the self-care deficit theory, aimed at caregivers of polytraumatized patients. In the end, the researchers concluded that the intervention program favored both the level of knowledge of the caregivers and the evolution and prevention of complications, such as pressure lesions in the polytraumatized patient.
Still on the use of Orem's theory as a teaching strategy, a Brazilian study ${ }^{11}$ reported the experience of developing a proposal for participatory health education aimed at selfcare for people with diabetes mellitus (DM), visualizing the prevention and care of diabetic foot complications.

From a group of 10 patients with DM, the authors based themselves on Paulo Freire's theory and liberating education as a health education strategy. At the end of the study, the authors reported the importance of the education proposal based on the Orem's theory in order to make self-care a reality and reduce the risks of developing the complication of diabetic foot, which brings repercussions for autonomy and well-being ${ }^{11}$.

The study developed in Iran also used theory as a teaching strategy, the authors developed a quasi-experimental study in which the intervention group received two self-care training sessions and home visits for 12 weeks, but the control group received only routine care. A significant difference was found between the two groups in relation to the mean scores of self-care, number of affected areas, ischemia, infection and healing phase of diabetic foot ulcers. Thus, the authors concluded that the application of the self-care model of Orem can be useful in the treatment of diabetic foot ulcers and can change the patients' lives, decreasing the risk of amputation and medical costs ${ }^{12}$.

Scientific evidence corroborates with the results of the studies described above, emphasizing that the operationalization of the nurse, who must prioritize the activities concerning his role as educator, is important for the involvement of patients in self-care activities, especially when deficit of knowledge and competence to care for himself is verified ${ }^{3}$. The authors emphasize that the success of the interventions depends on the patient's engagement and aptitude in his/her care ${ }^{4}$.

The articles that used the Orem's theory as theoretical reference in their researches reflect and evaluate the theory under a conceptual approach, with description of concepts referring to the relationship between the caregiver and the person being cared, such as the four fundamental concepts of nursing theories (metaparadigm of nursing) 4 $^{4}$

In a Brazilian study, through the interview of 7 primiparous puerperal adolescents, using the categorical analysis technique, and discussed based on Dorothea Orem's theoretical reference, the knowledge of puerperal adolescents about self-care related to breast care, intimate hygiene and surgical wounds, physical exercise, contraception, the benefits 
of breastfeeding, and the sociocultural influence on selfcare actions was identified. Thus, the authors concluded that adolescents need improvements in their preparation for self-care actions in the puerperium ${ }^{13}$.

The reflection study conducted in Colombia ${ }^{14}$ addresses a discussion on the responsibility of the nurse as a leader in wound care management. Based on Orem's theory, within the care clinic for people with skin integrity changes, the nurses (by tradition and history, knowledge, legal support and social commitment) implement the knowledge through state-of-the-art technology (latest generation dressings, creams, bandages, lotions and others), with the objective of offering comprehensive care to patients. The nurse is responsible for obtaining, applying and performing high technology for the treatment of wounds, in addition to guiding the health team in the continuous monitoring of users with injuries ${ }^{14}$.

In a study conducted through an interview with 10 users attended by the Complementary Assistance Program of a wound outpatient clinic in Brazil, through a thematic analysis of content, based on the nursing theory of selfcare deficit, it was possible to know the user's perception of self-care of lower limb ulcer ${ }^{15}$. It was concluded that selfcare results from the dialogue between user/nurse/health professionals and the bond established by them for shared care, with the support of family members and the network of services being a facilitator or limiter of care.

The studies conducted in the USA used Orem's theory as a theoretical reference and were published in 2009. One of them demonstrated the deficiency of the application of nursing theory in the specialized unit of burns and suggested the theoretical model of Orem as valid base to provide assistance and to increase the level of professionalism in this specialty ${ }^{16}$. The other study explored the relationship between glycated hemoglobin values and the healing time of leg and foot ulcers ${ }^{17}$.

Application of the Orem's theory in the systematization of nursing care (SNC) for the care of people with wounds goes beyond the simple act of performing a procedure (the dressing). From this perspective, Dorothea Orem's theory enables a greater understanding of the importance of continuing nursing care at home. The theory of self-care helps in defining roles and makes the patient as important as the role of the nurse ${ }^{21}$.

The only article that uses the theory in the SNC aims to validate an instrument for measuring self-care in patients with venous ulcer ${ }^{18}$. The instrument is a catalogue containing 59 activities aimed at self-care of the person with venous ulcer. Activities include questions related to the use of compressive therapy (stockings, elastic bandages), mobility, temperature, venous overload, preventive activities related to injury and wound healing.

Based on tests to evaluate psychometric scales (face validation, internal consistency, reliability), the instrument has been validated and is suitable for identifying self-care deficits of people with venous ulcers.

As noted in the discussion above, different methodological designs of studies conducted with different types of wounds were related to the theory of self-care. Living with wounds requires a significant change in the habits and behavior of people and their families, bringing suffering, fragility and disabilities to perform daily activities ${ }^{22}$.

A self-care deficit can lead to failure in the healing process, causing harm to patients and increasing the chances of wound recurrence; thus, it can increase treatment time and, consequently, health care expenditures ${ }^{23}$.

Thus, Orem's theory makes it possible to reflect on the potentials of the individual, forms and motivation for selfcare and, when this is not effective, to consider the need for care by other people, being recognized as something inherent to humanity ${ }^{4}$.

\section{CONCLUSION}

Over 34 years of existence, Dorothea Orem's theory of self-care deficit has developed and expanded worldwide. Thus, its validation is already something concrete, there is no doubt of its applicability in nursing, not even in the field of wounds. However, considering the findings of this review, the minimum number of published articles that apply the self-care theory in the field of wounds was observed, which reinforces the need to use this nursing theory to a greater extent in the field of research.

The appropriation of this theoretical construct is present in the theoretical basis of the studies, in clinical practice and in the teaching of the nursing area, as well as in the field of wounds, regardless of the type of injury.

It confirms that Orem's theory can and should be applied in a wide range of subjects and contexts. Therefore, the ability to adapt to different scenarios makes it an important tool to get to know the individual within his 
context and guide professional practice on the real needs of that human being.

\section{ACKNOWLEDGMENTS}

The authors thank the support of the Federal University of Alagoas.
AUTHOR'S CONTRIBUTION

Conceptualization, Melo LHA; Methodology, Melo LHA; Investigation, Melo LHA; Writing - Original Draft, Melo LHA, Bernardo THL, Macedo JKSS, Francisco LCFL and Barros AC; Writing - Review and Editing, Melo LHA, Bernardo THL, Macedo JKSS, Francisco LCFL and Barros AC; Supervision, Bernardo THL.

\section{REFERENCES}

1. Oliveira FP, Oliveira BGRB, Santana RF, Silva BP, Candido JSC. Classificações de intervenções e resultados de enfermagem em pacientes com feridas: mapeamento cruzado. Rev Gaúcha Enferm. 2016;37(2):e55033. https://doi.org/10.1590/1983-1447.2016.02.55033

2. Cavassan NRV, Camargo CC, Pontes LG, Barraviera B, Ferreira RS, Miot HA, et al. Correlation between chronic venous ulcer exudate proteins and clinical profile: a cross-sectional study. J Proteom. 2019;192:280-90. https://doi.org/10.1016/j.jprot.2018.09.009

3. Stadler DV, Giordani AT, Paulino GME, Sonobe HM, Zanardo RR, Valério MA. Estratégias para o ensino do autocuidado de pacientes cirúrgicos: uma revisão integrativa da literatura. Rev G\&S. 2019;00:128-41. https://doi.org/10.26512/gs.v0i0.23332

4. Bezerra MLR, Faria RPR, Jesus CAC, Reis PED, Pinho DLM, Kamada I. Aplicabilidade da teoria do déficit do autocuidado de Orem no Brasil: uma revisão integrativa. J Manag Prim Health Care. 2018;9:e16. https://doi. org/10.14295/jmphc.v9i0.538

5. Moreira LAB, Dias DS, Freitas MG, Alves ÁKP, Fernandes PKRS. A utilização da teoria do autocuidado na assistência a gestante portadora de HIV. In: VI Encontro de Monitoria e Iniciação Científica. Fortaleza: Conexão Fametro 2018: Criatividade e Inovação. XIV Semana Acadêmica; 2018.

6. Mendonça SCB, Zanetti ML, Sawada NO, Barreto IDC, Andrade JS, Otero LM. Construction and validation of the Self-care Assessment Instrument for patients with type 2 diabetes mellitus. Rev Latino-Am Enfermagem. 2017;25:e2890 https://doi.org/10.1590/15188345.1533 .2890

7. Grupo Ănima Educação. Manual de revisão bibliográfica sistemática integrativa: a pesquisa baseada em evidências. Belo Horizonte: Grupo Ănima Educação; 2014.

8. Borba AKOT, Arruda IKG, Marques APO, Leal MCC, Diniz AS. Conhecimento sobre o diabetes e atitude para o autocuidado de idosos na atenção primária à saúde.
Ciênc Saúde Coletiva. 2019;24(1):125-36. https://doi. org/10.1590/1413-81232018241.35052016

9. Herber OR, Schnepp W, Rieger MA. Developing a nurseled education program to enhance self-care agency in leg ulcer patients. Nurs Sci Q. 2008;21(2):150-55. https:// doi.org/10.1177/0894318408314694

10. Flores YYR, Flores MMH, Rangel MG. Enseñar a quien cuida el arte de cuidar: un programa educativo con cuidadores de pacientes politraumatizados. Invest Educ Enferm. 2010;28(1):73-82.

11. Coelho MS, Silva DMGV. Grupo educação-apoio: visualizando o autocuidado com os pés de pessoas com diabetes mellitus. Cienc Cuid Saúde. 2006;5(1):11-5.

12. Maslakpak MH, Shahbaz A, Parizad N, Ghafourifard M. Preventing and managing diabetic foot ulcers: application of Orem's self-care model. Int J Diabetes Dev Ctries. 2017;38:165-72. https://doi.org/10.1007/s13410017-0570-5

13. Lima GKS, Santos AAP, Silva JMO, Comassetto I, Correia SR, Ferreira DCS. Autocuidado de adolescentes no período puerperal: aplicação da teoria de Orem. Rev Enferm UFPE online. 2017;11(10 Suppl):4217-25.

14. Consuegra RVG. Gerencia del cuidado: liderazgo de la enfermera en el cuidado de la persona con alteración de los tejidos. Av Enferm. 2007;25(1):122-9.

15. Garcia AB, Müller PV, Paz PO, Duarte ERM, Kaiser DE. Percepção do usuário no autocuidado de úlcera em membros inferiores. Rev Gaúcha Enferm. 2018;39:e20170095. https://doi.org/10.1590/1983-1447.2018.20170095

16. Wilson J, Gramling L. The application of Orem's self-care model to burn care. J Burn Care Res. 2009;30(5):852-8. https://doi.org/10.1097/BCR.0b013e3181b48a2d

17. Markuson M, Hanson D, Anderson J, Langemo D, Hunter S, Thompson $\mathrm{P}$, et al. The relationship between hemoglobin A1C values and healing time for lower extremity ulcers in individuals with diabetes. Adv Skin Wound Care. 2009;22(8):365-72. https://doi. org/10.1097/01.ASW.0000358639.45784.cd 
18. Panfil E-M, Mayer H, Evers GCM. Entwicklung des «Wittener Aktivitätenkatalogs der Selbstpflege bei venös bedingten offenen Beinen» (WAS-VOB) [Desenvolvimento do "Catálogo de atividade Whittener de autocuidado em úlcera venosa"]. Pflege. 2004;17(1):28-35. Alemão. https://doi.org/10.1024/1012-5302.17.1.28

19. Monteiro LM, Spiri WC. Indicadores de qualidade e carga de trabalho uma revisão integrativa em enfermagem. REME - Rev Min Enferm. 2016;20:e936. https://doi. org/10.5935/1415-2762.20160006
20. Thomé A. A evolução da produção científica brasileira. RFO UPF. 2019;24(1):6-7. https://doi.org/10.5335/rfo.v24i1.9239

21. Blanck M, Giannini T. Úlcera e feridas, as feridas têm alma. Uma abordagem interdisciplinar do plano de cuidados e da reconstrução estética. Rio de Janeiro: Dilivros, 2014.

22. Geovanini T. Tratado de feridas e curativos - enfoque multiprofissional. São Paulo: Rideel; 2014.

23. Fonseca PMM, Soares TB. A atuação da equipe de enfermagem frente aos cuidados do paciente portador de ferida venosa. Rev Cient UMC. 2019;4(1):1-15. 